\title{
Reconstruction of Tissue Defects Developing After Excision of Non-Melanoma Malignant Skin Tumors in Scalp and Forehead Regions
}

\author{
Skalp ve Alun Bölgesinde Non-Melanoma Deri Tümörü Eksizyonu \\ Sonrası Defekt Rekonstrüksiyonu
}

Murat IGDE, Sedat YILANCI, Yagmur Yaprak BALI, R. Erkin UNLU, Serdar DUZGUN, Ilhan PEKDEMIR

Ankara Numune Training and Research Hospital, Department of Plastic, Reconstructive and Aesthetic Surgery, Ankara, Turkey

Corresponding Author: Yağmur Yaprak BALI / E-mail: dr_yyaprak@hotmail.com

\begin{abstract}
AIM: The scalp and forehead are the anatomical regions where non-melanoma malignant skin tumors are commonly seen due to direct sun exposure. After surgery for non-melanoma malignant skin tumors located in the scalp and forehead, many complex defects can develop, ranging from sole skin defects to deep defects in which bone and dura mater are opened.

MATERIAL and METHODS: This study examined 43 patients who presented to the Department of Plastic Surgery in Ankara Numune Training and Research Hospital and were diagnosed with non-melanoma malignant tumors of scalp and forehead between 2006 and 2013 . The number of operations, the operation techniques applied, the number and type of complications (if any) of free tissue transplantation were also investigated. Various techniques are used for reconstruction of scalp and forehead region following resection of non-melanoma skin tumors.

RESULTS: In order to accomplish satisfactory results these patients have to be carefully assessed with specific parameters while performing the reconstruction of the defect and reconstruction should be planned. Patients with local invasion may need adjuvant radiotherapy postoperatively and reconstruction with free flaps is reliable in the prevention of the possible comorbid problems due to radiotherapy.

CONCLUSION: Multidisciplinary approach is needed and the treatment should be managed with neurosurgical team, radiation oncologists and medical oncologists.
\end{abstract}

KEYWORDS: Forehead, Non-melanoma tumors, Reconstruction, Scalp

Öz

AMAÇ: Skalp ve alın güneşe direkt maruziyetinden dolayı non-melanoma malign deri tümörlerinin sık görüldüğü bir anatomik bölgedir. Skalp ve alında melanom dışı malign deri tümörleri cerrahisi sonrası sadece cilt defektinin olduğu defektlerden kemik ve dura mater'in açık olduğu defektlere kadar birçok kompleks defekt ortaya çıkabilir.

YÖNTEM ve GEREÇLER: Çalışmada 2006-2013 yılları arasında Ankara Numune Eğitim ve Araştırma Hastanesi Plastik Cerrahi Kliniği'ne başvurmuş, saçlı deri ve alında melanom dışı malign tümör tespit edilmiş olan 43 hasta incelenmiştir. Hastaların tıbbi kayıtları ve fotoğrafları incelenmiştir. Hastaların demografik bilgileri, meslek bilgileri, hastalık hikayesi, beraberinde bulunan ek hastalıkları, patoloji sonuçları, takipleri ve sonuçları incelenmiştir. Saçlı deri ve alında non-melanomik malign deri tümörleri sonucu oluşan defektlerin rekonstrüksiyonunda birçok yöntem kullanılmaktadır.

BULGULAR: Tatmin edici uzun dönem sonuçların elde edilebilmesi için bu hastaların defektlerinin rekonstrüksiyonu yapılırken hastaya özel parametreler dikkatlice değerlendirilmeli ve rekonstrüksiyonu planlanmalıdır.

SONUÇ: Saçı deri ve alında non-melanomik malign tümörler sonucu oluşan defektlerin rekonstrüksiyonu gerek operasyon sırasında gerekse operasyon sonrasında oluşabilecek komplikasyonlar nedeni ile multidisipliner yaklaşım gerektirmektedir.

ANAHTAR SÖZCÜKLER: Alın, Melanoma olmayan tümörler, Rekonstrüksiyon, Saçlı deri

\section{INTRODUCTION}

Scalp and forehead are the anatomical regions where nonmelanoma malignant skin tumors are commonly seen due to direct sun exposure. After surgery for non-melanoma malignant skin tumors located in scalp and forehead, many complex defects can develop, ranging from sole skin defects to deep defects in which bone and dura mater are opened. Co-morbid diseases that are prevalent in patients with non- melanotic skin cancers as a result of their advanced age as well as adjuvant radiotherapy complicate reconstructive efforts after surgery in both regions. Reconstruction of the patients scheduled for radiation is controversial and radiotherapy is usually left after reconstruction (16).

Lower soft tissue laxity and presence of hair follicles in hairy skin make defect reconstruction complex. Blood supply of hairy skin comes from external and internal carotid artery 
systems. Supratrochlear artery and supraorbital artery that are the terminal branches of ophthalmic artery branching off internal carotid artery, which also supply the forehead region, as well as superficial temporal artery, posterior auricular artery, and occipital artery that are branches of external carotid artery supply hairy skin. The plexus formed at the subdermal plane provides this region with a richer circulation compared to other parts of human body. Care should be taken not to injure this vascular network during local flap use.

In the forehead region, that is important for an aesthetic look, care should be taken not to damage eyebrow lines and the hair line starting from the frontal region. The frontal hair line is straight in women while it is a straight line in frontal region but turns into a convex line in temporal regions in men. The eyebrows are located on the supraorbital rim medially in women and men, and it ends at the level of lateral cantus as a straight line in men. In women, on the other hand, the eye brows start from medial side, peak at the level of lateral limbus, and terminate at the level of lateral cantus (16).

Depending on defect's localization and type, there are different reconstruction options for the defects on hairy skin and forehead, including allowing secondary healing, primary closure, vacuum-assisted closure, local flap use, closure via expander applications, and closure with free flap. Before using any of these methods, the defect should be completely cleared from tumor $(5,7)$. In small defects (Figures 1-4), primary closure or, in cases with preserved periosteum, allowing secondary healing and closure with skin grafts are the preferred closure methods $(6,18)$. In cases where periosteum is absent and the bone is exposed, boring a hole with a drill in the bone until the diploic layer and skin grafting after formation of granulation tissue is another option (3). Single or multiple rotation flaps and distant pedicle flaps are used in moderate-sized defects $(1,9,13)$. Latissimus dorsi, trapezius, and pectoral pedicled myocutaneous flaps may also be used in lateral and occipital scalp $(11,12)$. A long reconstruction time and a high complication rate have reduced expander use but it is an aesthetically useful technique (2) since it gives better results with skin color and texture harmony. Free flaps are an excellent option for the reconstruction of large defects since the procedure can be complete in a single session and these flaps provide the necessary amount of tissue (6). However, they also have disadvantages including a long operation time, possibility of flap loss, and containing no hair follicle (4).

The aim of the present study was to assess the outcomes and complications of the defect reconstruction techniques and compare their relative efficacy after surgery for non-melanotic malignant tumors of scalp and forehead in 43 patients.

\section{MATERIAL and METHODS}

This study examined 43 patients who presented to the Department of Plastic Surgery in Ankara Numune Training and Research Hospital and were diagnosed with non- melanoma malignant tumors of scalp and forehead between 2006 and 2013. Patients with frontal sinus and orbital tumor invasion were excluded. Medical records and photographs of the patients were reviewed. Demographic properties, occupational information, history of any illness, co-morbidities, pathology results, follow-up data, and outcomes were analyzed. The number of operations, the operation techniques applied, the number and the type of complications (if any) of free tissue transplantation were also investigated.

Among patients operated with an initial diagnosis of nonmelanotic malignant tumor, those with no bone infiltration as demonstrated by computed tomography (CT) underwent tumor excision, including periosteum, with a $1 \mathrm{~cm}$ safety margin. The bone biopsy specimens taken from the lesion floor were sent for frozen examination. Patients with a negative frozen examination underwent reconstruction at the same session. A full thickness bone resection was carried out and the resulting defect was reconstructed with muscle flaps in patients with a positive frozen examination.

Among patients who were operated for an initial diagnosis of non-melanotic tumor, the depth of excision for those with bone infiltration demonstrated by CT was extended to dura mater and reconstruction was carried out in the same session when intraoperative frozen examination revealed dura mater infiltration. Patients with brain parenchymal infiltration were considered inoperable and consulted with neurosurgery and medical oncology department for adjuvant therapy. A complete tumor clearance from surgical borders was considered a prerequisite for planning reconstruction in both groups.

All patients having a macroscopically visible tumor underwent a CT for dura mater invasion and/or bone invasion. Each patient with dura mater or bone invasion was consulted with the Neurosurgery Department of our hospital and the operation was performed jointly with a team from that department.

\section{RESULTS}

This study examined 43 patients with extensive local nonmelanotic malignant tumor in forehead and scalp. The distribution of non-melanotic malignant tumor localization was as follows: 15 tumors in forehead (frontal) (Figures 1-4), 13 in temporal region (Figure 5), 4 in parietal region (Figures $6,7), 5$ in occipital region, and 6 in vertex (Table I). Twentyseven patients had squamous cell carcinoma (SCC) and 16 had basal cell carcinoma (BCC) (Table I). To rule out bone invasion the patients were examined with a preoperative CT that showed bone invasion in 10 patients. All patients were applied reconstruction in the same session. Reconstruction included a partial thickness skin graft in 13 patients, a local flap in 18, a distant flap in 7, and a free flap in 5 (Table II).

Analysis of the demographic properties of the patients revealed that 17 female and 26 male patients were operated. The mean age of the patient population was 62.4 years 
(48-87 years). A review of the working conditions of the patients showed that 17 patients were farmers and 11 were construction workers who had been exposed to a high level of sunlight. Other 15 patients had jobs with no sunlight exposure.

Periosteum was included in the excision material and sent for frozen examination together with bone biopsy samples in 33 patients who had no bone invasion on computed tomography and were operated. Among these patients, 2 underwent bone resection owing to positive bone invasion. Reconstruction was performed in the same session in all of the 33 patients who were operated. In 13 of them, surfaces of the cranial bones were trimmed and reconstructed with a partial thickness skin graft to allow granulation tissue to grow. A flap reconstruction was carried out in 18 patients. Reconstruction with a distant flap (trapezius muscle flap) was done in 2 patients with bone invasion that was not detected by CT but confirmed by frozen examination.

Table I: Tumor Pathology and Localization

\begin{tabular}{|c|c|c|c|c|c|} 
& $\begin{array}{c}\text { Forehead/Frontal } \\
\text { Region }\end{array}$ & $\begin{array}{c}\text { Parietal } \\
\text { Region }\end{array}$ & $\begin{array}{c}\text { Temporal } \\
\text { Region }\end{array}$ & $\begin{array}{c}\text { Occipital } \\
\text { Region }\end{array}$ & Vertex \\
SCC & 11 & 3 & 6 & 3 & 2 \\
BCC & 4 & 1 & 7 & 2 & 4 \\
\hline
\end{tabular}

SCC; Squamous Cell Carcinoma, BCC; Basal Cell Carcinoma.

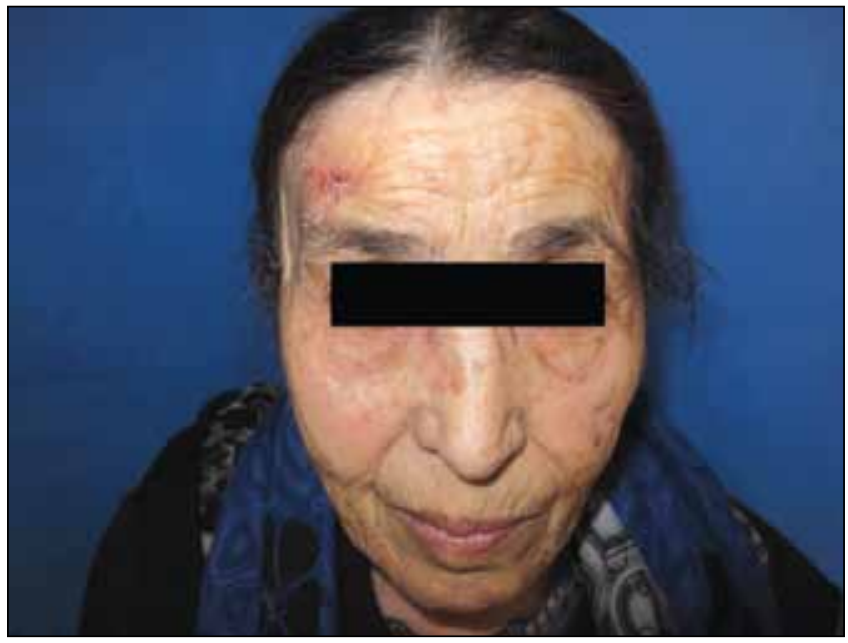

Figure 1: Preoperative view of patient with $B C C$ in the frontal region.

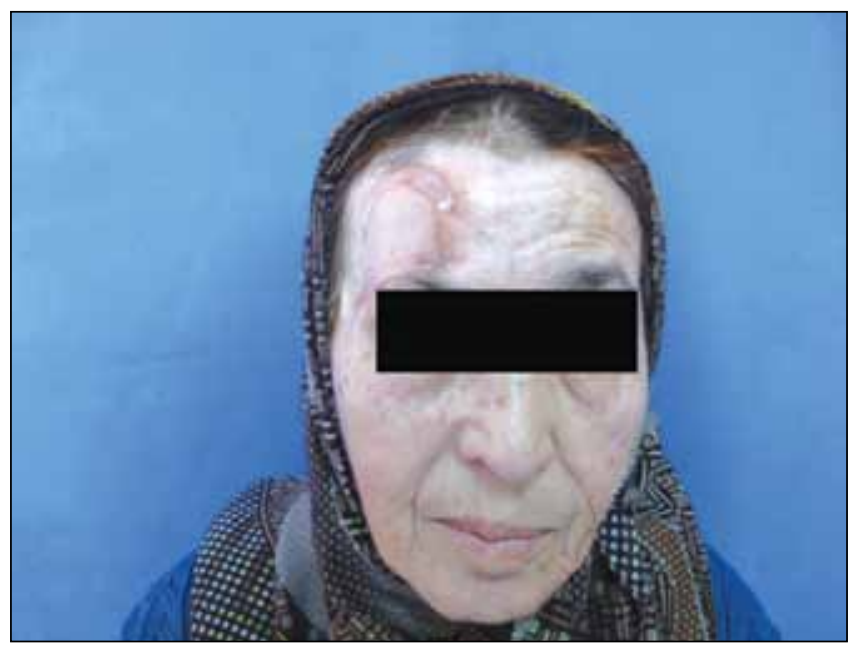

Figure 3: Postoperative view of the patient, reconstructed with graft.

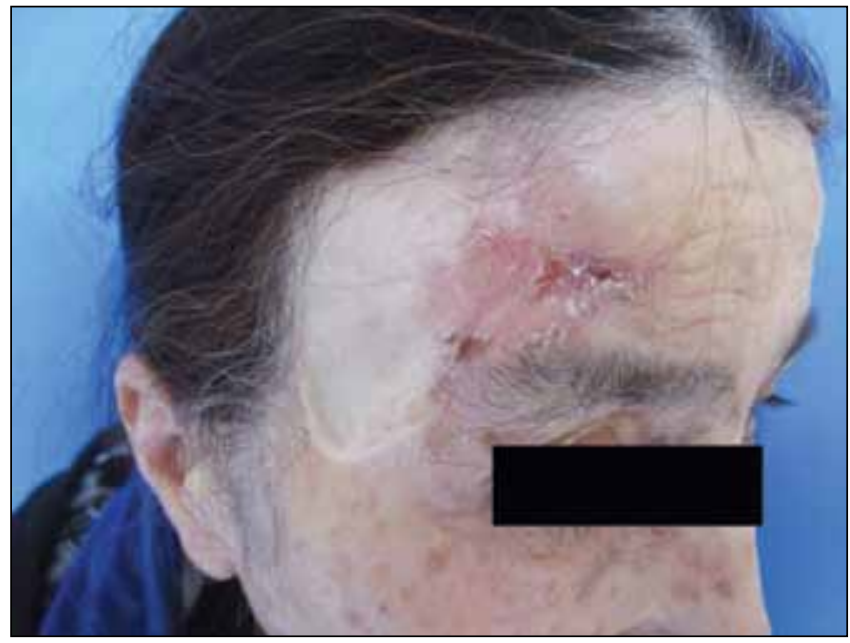

Figure 2: More closer view of the same patient with $B C C$ in the frontal region.

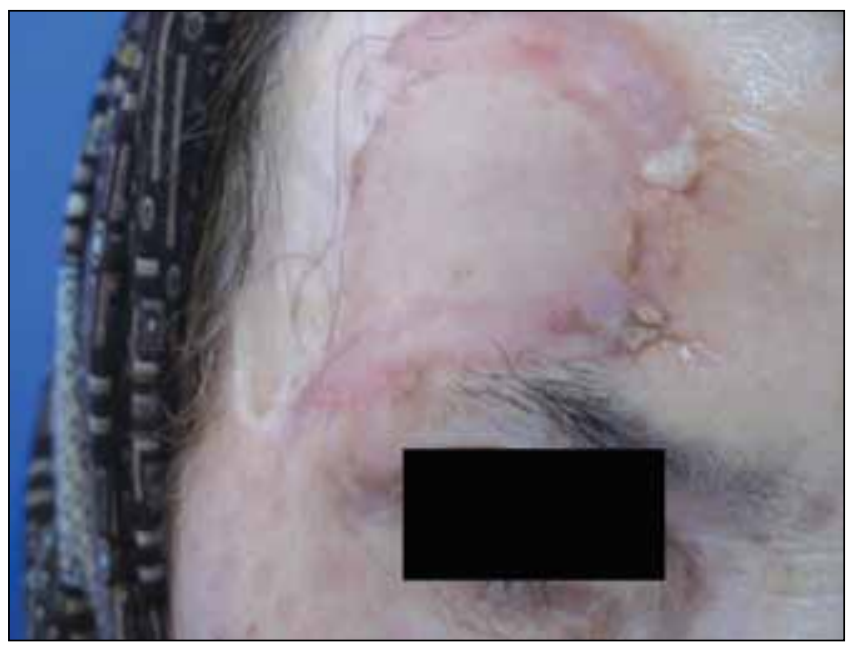

Figure 4: More closer view of the same patient, reconstructed with graft. 
In 10 patients who had bone invasion demonstrated by CT and were then operated, pathology samples taken from dura mater after bone resection were sent for frozen examination. Five of them revealed no dura mater invasion whereas 4 showed dura mater invasion and one showed parenchymal invasion. All patients were applied duraplasty with a tensor fascia lata graft by neurosurgery team and 3 of 5 patients with no dura mater invasion were reconstructed with a distant flap (trapezius muscle flap) and 2 with a free flap (2 latissimus dorsi muscle flap). Two of 4 patients with dura mater invasion underwent distant flap (trapezius muscle flap) reconstruction and 2 underwent free flap ( 1 radial forearm muscle flap, 1 latissimus dorsi muscle flap) reconstruction after duraplasty. One patient with dura mater invasion had macroscopically and tomographically evident parenchymal invasion. In that patient, bone excision and duraplasty were performed in addition to excision of ulcerated lesion, and a reconstruction using a free tissue flap (latissimus dorsi musculocutaneous

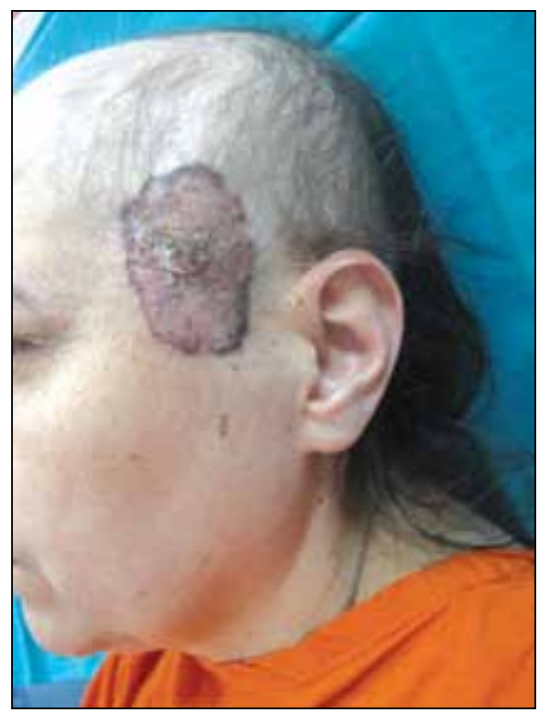

Figure 5: The patient with SCC in the temporal region.

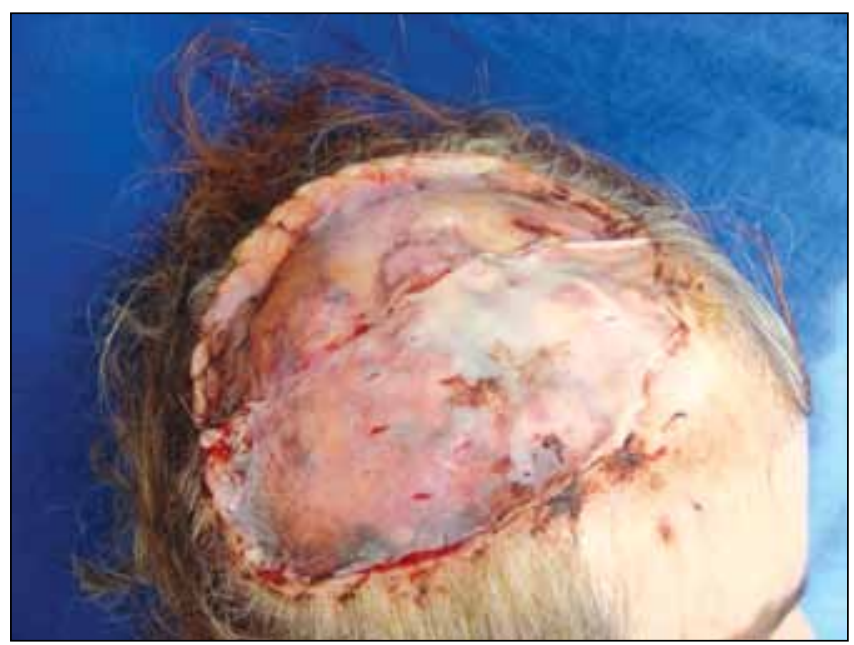

Figure 7: Postoperative view of the patient with SCC in the parietal region, reconstructed with graft. graft) was applied (Figures 8-11). The patient was then consulted with the medical oncology department and transferred to the radiation oncology department for adjuvant therapy.

Fifteen of 18 patients undergoing reconstruction with a partial thickness skin graft experienced no complications while 2 developed graft lysis and 1 developed a hematoma under the graft. Three patients in whom a complication emerged were re-operated and the same treatment was administered. No complication occurred in 16 of 18 patients in whom a local flap was used while 2 patients developed a hematoma that was evacuated and flap loss was averted. No flap loss was observed in 7 patients with distant flap application while 6 patients developed a seroma formation in trapezius muscle flap donor area. At the end of an approximately 2-week followup period, all donor areas completely improved without a complication. Postoperative venous thrombosis was

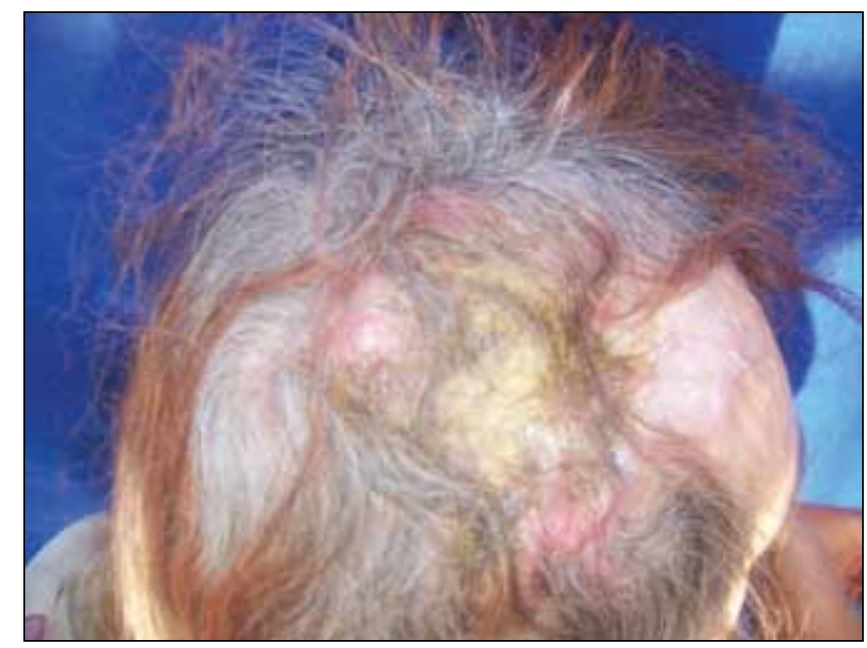

Figure 6: Preoperative view of the patient with SCC in the parietal region.

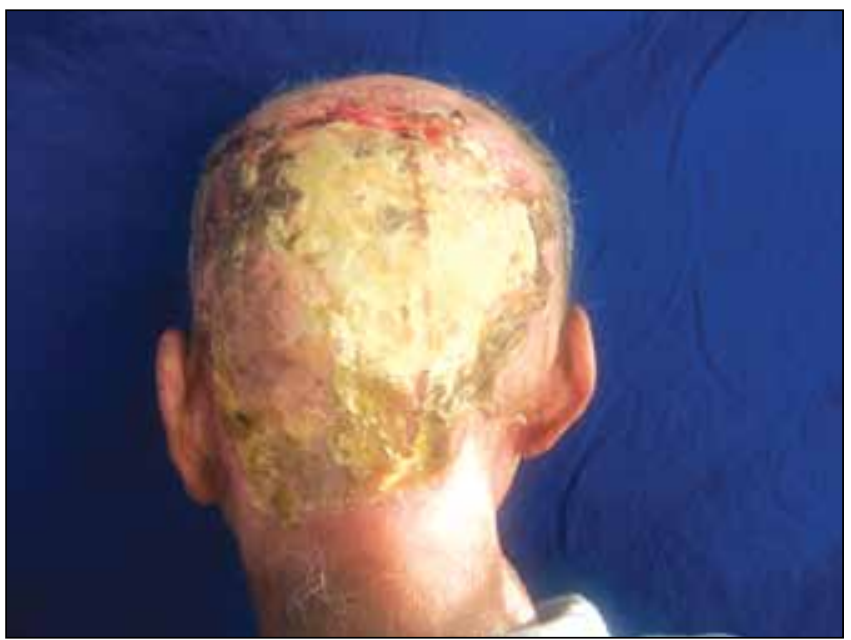

Figure 8: Preoperative posterior view of the patient with SCC. 


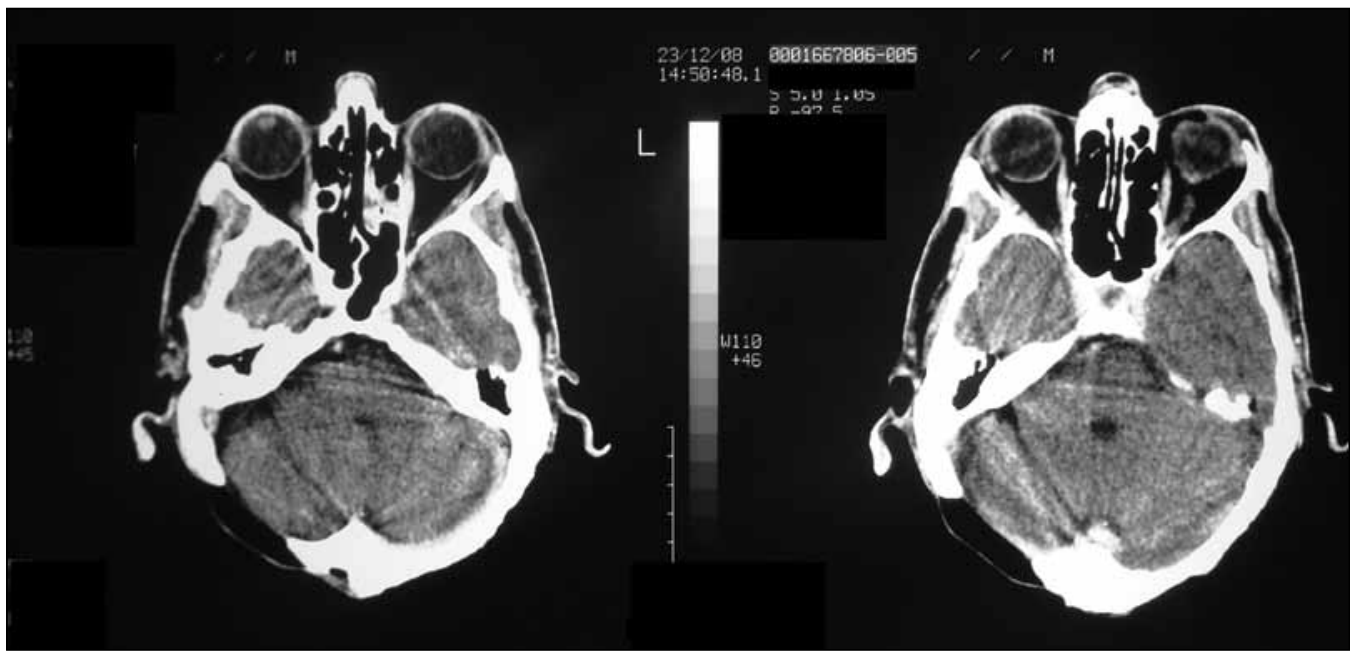

Figure 9: Craniectomy defect of the same patient in the parietal region due to bone invasion.

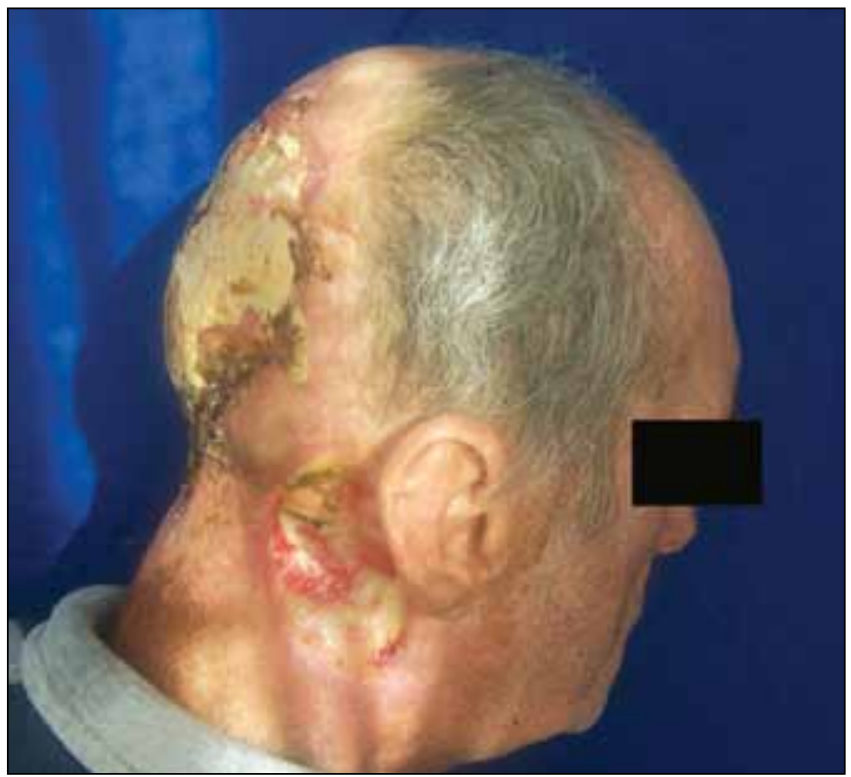

Figure 10: Postoperative lateral view of the same patient.

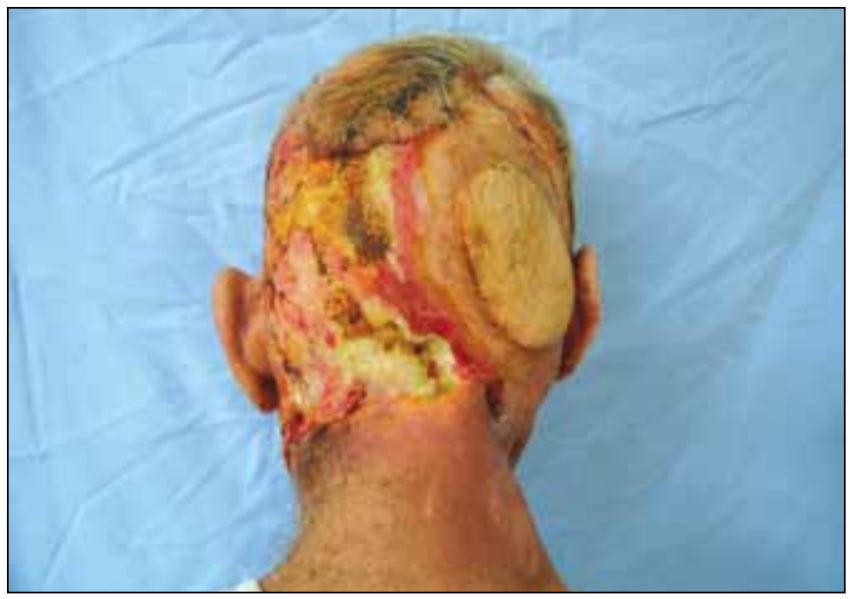

Figure 11: Postoperative posterior view of the same patient. The defect closed with latissimus dorsi myocutaneous flap. observed in 2 of 5 patients, who underwent reconstruction with a free tissue flap, and then 2 patients were re-operated to renew anastomosis; as a result, no flap loss occurred. Three of 4 patients undergoing reconstruction with latissimus dorsi flap suffered a seroma in the donor area. Fortunately, all donor areas were cured without any complication at the end of a 2-week observation period.

Routine follow-up appointments were begun after operations. None of 43 patients enrolled in the study experienced a major complication from the operation. One patient with brain parenchyma invasion was lost at postoperative $13^{\text {th }}$ month. Three operated patients developed local recurrences and 2 developed a secondary tumor in another location of forehead or scalp. Necessary operations were scheduled and the patients were re-operated. The patients were followed for an average duration of 60 months (13 months to 96 months).

\section{DISCUSSION}

Scalp and forehead reconstruction appear relatively simple at initial admission; however, they become complicated due to previous radiotherapy sessions, presence of cranioplasty, or presence of non-vascularized bone secondary to craniotomy. Defects frequently develop arise to oncological resections, trauma, electric burns, infection, and radiotherapy. The main factors determining the reconstruction options are defect size and localization, periosteal thickness, and the remaining scalp tissue. An ideal reconstruction option should be durable and resistant against conditions like postoperative wound dehiscence. In addition, it should only minimally affect the hairline, alopecia areas, and direction of hair follicles.

While small, partial thickness defects are allowed to heal secondarily, large defects with exposed dura and parenchyma should be repaired with free flap reconstruction. As a general rule, defects smaller than $3 \mathrm{~cm}^{2}$ can be closed primarily while defects with a size of $3-6 \mathrm{~cm}^{2}$ can be reconstructed with local 
rotation or transposition flaps, and defects larger than $9 \mathrm{~cm}^{2}$ with free flaps $(8,15)$. In addition to size-based treatment selection, reconstruction with a free flap should be preferred in postsurgical composite tissue losses. As the scalp is a nonflexible region, the flap length can be adjusted with galeal scoring when the planned flaps fail to cover the defect.

Blood supply of scalp is an important factor particularly for flap planning. Thus, previous operations and the status of superficial temporal artery, occipital artery, posterior auricular artery, and supratrochlear and supraorbital arteries should be taken into account during preoperative assessment. Vascularity is important for local flap selection. Furthermore, free flap is used for recipient vessel and takes an important place in planning.

Forehead reconstruction is similar to scalp reconstruction. An aesthetic look is an important concern in this region, and care should be taken not to distort eyebrow lines and hairline starting from frontal region. Women have a straight frontal hair line while men have a straight frontal hair line that turns into a convex line in temporal area. Eyebrows are located over the supraorbital rim medially in both women and men, and terminate at the level of lateral cantus as a straight line in men. In women, eyebrows start medially, peak at the level of lateral limbus, and terminate at the level of lateral cantus. A primary closure should be as parallel to horizontal forehead line as possible $(10,14,17)$, and care should be taken not to cause eyebrow and upper eyelid distortion. A vertical closure can also sometimes be used to minimize eyebrow distortion. Forehead defects can be closed with local flaps or tissue expansion up to $40-50 \%$ of time. Again, a supratrochlear and supraorbital artery-based paramedian forehead flap is among primary local closure options. Superficial temporal fascia flap and temporal muscle flap are also commonly preferred due to their proximity to forehead (17).

Tissue expansion, similarly in scalp and forehead, is commonly used for obtaining a large tissue when a single-session closure is not needed.

Patients, having large tissue defects, without bone infiltration but with systemic disorders hampering free flap operation underwent upper cortex decortication followed by reconstruction with partial thickness skin graft.

Free tissue transfer is usually preferred in cases where defect size is larger than $9 \mathrm{~cm}^{2}$, and deperiosted bone, dura mater, or parenchyma is exposed at the floor. It is commonly used in large defects of forehead. Since forehead skin is thinner and constitutes an important aesthetic unit, thin fasciocutaneous flaps such as radial forearm or lateral arm are frequently preferred (14). In scalp, on the other hand, free flap options are more in number based on defect size and predicted aesthetic benefits. Musculocutaneous flaps like latissimus dorsi and rectus abdominis are preferred in craniotomy defects while fasciocutaneous flaps provide a better aesthetic look in noncomposite defects. In scalp reconstruction, the disadvantage of free flaps is that they contain insufficient amount of hair follicles. In our study, latissimus dorsi musculocutaneous flap was used in patients with craniotomy defects.

Craniectomy is performed when SCC- or BCC-induced cranium invasion occurs. Craniectomy defect is not reconstructed until surgical margins are reported by pathology department (11). Dura is covered with local or distant flaps. The Neurosurgery team closed the craniectomy defect with implants or bone graft after excision margin is reported negative (11). Dural excision and duraplasty either with galea or superficial temporal fascia are performed in cases where bone and dural invasion accompany clinical picture. The region of duraplasty should be reconstructed with musculocutaneous flaps whenever possible if bone reconstruction is not contemplated in this region.

\section{CONCLUSION}

Various techniques are used for reconstruction of scalp and forehead region following resection of non-melanoma skin tumors. In order to accomplish satisfactory results, these patients have to be carefully assessed with specific parameters while performing the reconstruction of the defect and reconstruction should be planned.

In the cases with dura mater and bone invasion of the tumor, recurrence rates are fairly high. For this reason, in such cases excision margins should be wide and reconstruction is achieved with free tissue transfers. Patients with local invasion may need adjuvant radiotherapy postoperatively and reconstruction with free flaps are reliable in prevention of the possible comorbid problems due to radiotherapy. In conclusion, reconstruction of the defects in the scalp and forehead region caused by non-melanoma malign tumor resection require multidisciplinary approach, due to possible complications that can occur during or following the surgery. Multidisciplinary approach is needed and the whole treatment should be managed with the neurosurgical team, radiation oncologists and medical oncologists (11).

\section{REFERENCES}

1. De Haro F, Giraldo F: Bipedicled fronto-occipital flap for reconstruction of postoncologic defects of the lateral scalp. Plast Reconstr Surg 107:506-510, 2001

2. Frodel JL Jr, Ahlstrom K: Reconstruction of complex scalp defects. Arch Facial Plast Surg 6:54-60, 2004

3. Furnas $H$, Lineaweaver WC, Alpert BS, Buncke HJ: Scalp reconstruction by microvascular free tissue transfer. Ann Plast Surg 24:431-444, 1990

4. Genden EM, Rinaldo A, Sua'rez C, Wei WI, Bradley PJ, Ferlito A: Complications of free flap transfer for head and neck reconstruction following cancer resection. Oral Oncol 40:979-984, 2004

5. Hoffmann JF: Management of scalp defects. Otolaryngol Clin North Am 34:571-582, 2001

6. Hussussian CJ, Reece GP: Microsurgical scalp reconstruction in the patient with cancer. Plast Reconstr Surg 109:18281834,2002 
7. Kroll SS, Margolis R: Scalp flap rotation with primary donor site closure. Ann Plast Surg 30:452-455, 1993

8. Larrañaga J, Rios A, Franciosi E, Mazzaro E, Figari M: Free flap reconstruction for complex scalp and forehead defects with associated full-thickness calvarial bone resections. Craniomaxillofac Trauma Reconstr 5(4):205-212, 2012

9. Lesavoy MA, Dubrow TJ, Schwartz RJ, Wackym PA, Eisenhauer DM, McGuire M: Management of large scalp defects with local pedicle flaps. Plast Reconstr Surg 91:783-790, 1993

10. Lynch JR, Hansen JE, Chaffoo R, Seyfer AE: The lower trapezius musculocutaneous flap revisited: Versatile coverage for complicated wounds to the posterior cervical and occipital regions based on the deep branch of the transverse cervical artery. Plast Reconstr Surg 109:444, 2002

11. Hanasono MM: Scalp and Forehead Reconstruction. In: Gregory RD Evans (ed), Head and Neck Reconstruction. Charles E Butler, FL: Elseiver Press, 2009: 39-53

12. Maxwell GP, Leonard LG, Manson PN, Hoopes JE: Craniofacial coverage using the latissimus dorsi myocutaneous island flap. Ann Plast Surg 4:410-421, 1980
13. Orticochea M: Four flap scalp reconstruction technique. $\mathrm{Br} \mathrm{J}$ Plast Surg 20:159-171, 1967

14. Ozalp B, Karaaltin MV, Cavdar G, Elbey H: Subgalealsubperiosteal flap for forehead and scalp reconstruction. J Craniofac Surg 23(6):e562-564, 2012

15. Rao J, Deora H: Surgical excision with forehead flap as single modality treatment for Basal cell cancer of central face: Single institutional experience of 50 cases. J Skin Cancer 320792, 2014

16. Robson MC, Zachary LS, Schmidt DR, Faibisoff B, Hekmatpanah J: Reconstruction of large cranial defects in the presence of heavy radiation damage and infection utilizing tissue transferred by microvascular anastomoses. Plast Reconstr Surg 83:438-442, 1989

17. Tenna S, Brunetti B, Aveta A, Poccia I, Persichetti P: Scalp reconstruction with superficial temporal artery island flap: Clinical experience on 30 consecutive cases. J Plast Reconstr Aesthet Surg 66(5):660-666, 2013

18. TerKonda RP, Sykes JM: Concepts in scalp and forehead reconstruction. Otolaryngol Clin North Am 30:519-539, 1997 